\section{Marquette University \\ e-Publications@Marquette}

Languages, Literatures and Culture Faculty

Research and Publications

Fall 2020

\title{
Palestinian American Women and Marital Choices Across Generations
}

Enaya Othman

Marquette University, enaya.othman@marquette.edu

Follow this and additional works at: https://epublications.marquette.edu/arabic

\section{Recommended Citation}

Othman, Enaya, "Palestinian American Women and Marital Choices Across Generations" (2020). Arabic Languages and Literatures. 7.

https://epublications.marquette.edu/arabic/7 
Marquette University

e-Publications@Marquette

\title{
Arabic Languages and Literatures Faculty Research and Publications/College of Arts and Sciences
}

This paper is NOT THE PUBLISHED VERSION.

Access the published version via the link in the citation below.

Journal of American Ethnic History, Vol. 40, No. 1 (Fall 2020): 70-91. DOI. This article is @ University of Illinois Press and permission has been granted for this version to appear in e-Publications@Marquette. University of Illinois Press does not grant permission for this article to be further copied/distributed or hosted elsewhere without the express permission from University of Illinois Press.

\section{Palestinian American Women and Marital Choices Across Generations}

\author{
ENAYA HAMMAD OTHMAN
}

\begin{abstract}
This paper examines Palestinian women's marriage preferences and the ways they incorporate national/cultural elements into their self-initiated marriage process in order to mitigate the reactions of their families and local community in Milwaukee, Wisconsin. Marriage decisions among Palestinians in diaspora are a complex affair defined by notions of nationalism, kin relations, and religion, with their inherent gendered aspects. These notions reveal an array of actions and choices that testify to the ways in which women build strategies to deal with their realities and increase their agency. Their access to higher education, careers, and residences in multi-cultural locations allow them to redefine gender roles and control their marriage choices. Intermarriage outside their ethnic and national groups, increase in marriage age, and marriage processes that are self-initiated yet devised and presented in the form of customary marriage patterns emerge as visible phenomena among secondgeneration Palestinian Muslims. The decreasing number of suitable potential spouses drives a considerable number of Palestinian American women to look outside their national and ethnic group for marriage partners, thereby prioritizing their universal, religious identity as Muslims over Palestinian ethnic identity. This study uses oral interviews and community observation to examine how Palestinian Muslim women maintained some
\end{abstract}


symbolic customary practices and challenged others by conceptualizing, utilizing, and modifying their group cultural and religious values in order to expand the boundaries of their gender roles and increase their power in negotiating marriage choices.

\section{INTRODUCTION}

This study explores the marriage patterns among Muslim Palestinians in Milwaukee, Wisconsin, with a focus on two distinctive periods: the 1950s-1980s and 1990s-2000s. The study reflects women's perspectives on partner criteria, family involvement, and wedding celebrations as cultural particularities that have been confirmed, transformed, or challenged in relation to the demographic and social environments and the strategic use of multiple, fluid, and more prevailingly Muslim identities. The study utilizes forty oral interviews conducted with immigrant and second-generation women members of the Palestinian community in Milwaukee. ${ }^{1}$ Milwaukee is representative of a mid-sized American city in the Midwest with a significant increase in its Muslim population since the early 1990s. It is also home to a large and growing number of Muslim institutions and mosques. Of the Arab residents in Milwaukee, Palestinian Muslims have been the largest population since their arrival in significant numbers after WWII. ${ }^{2}$ They have made significant contributions to definitions of Arab and Palestinian nationalism and to the social, political, and cultural activities of the Muslim communities in the area. ${ }^{3}$ As a member of the Arab and Muslim community in Milwaukee for the last three decades, I use my personal observations in addition to scholarly research, community members' photographs, and focus-group discussions. The majority of the interviews were conducted between 2010 and 2018 by a group of college student interviewers. The interviewers were trained in the methods of conducting oral history interviews through the Arab and Muslim Women's Research and Resource Institute (AMWRRI) ${ }^{4}$ workshops and by taking a college class at Marquette University on Muslim women in the United States. The methods of collecting in-depth oral interviews were major components of the class's educational objectives. Two of the interviews were conducted by the author in 1997 as part of a graduate research project. Most of these interviews were conducted in English. Two interviews were conducted in both Arabic and English. Interviewees have been given pseudonyms to conceal their identity.

This paper reveals the existence of multiple discourses that uncover the complexity and contradiction of Palestinian women's realities as reflected in marriage patterns. In Milwaukee, Palestinian Muslim women have experienced different kinds of marriage processes depending on the period they/ their parents arrived in the United States, their education level, availability of compatible Palestinian spouses, and socialization outside their parents' national origins. In addition, Palestinians' historical and contemporary reality as a stateless population has greatly contributed to the preference of Palestinian women to marry a partner from the same cultural background if a suitable partner is available. This preference is part of the dynamic between diaspora and homeland in which a feeling of disparity regarding their displacement and the unjust treatment of their people in the homeland strengthen their identity as Palestinians. In this way, while women tend to select their own spouses, maintenance of marriage customs is a form of resistance to sustain their existence as a national and cultural group. Thus, the shift to religious identification among American Palestinians does not mean the dismissal of homeland national politics, identity, and practices. On the contrary, Benedict Anderson's notion of "long-distance nationalism" is strong among Palestinians living in diaspora. Women's endeavors and belief in safeguarding and protecting their group heritage and customs are related to living outside their homeland and in a multi-cultural location, which enables them to inhabit "diasporic identities" and is a reflection of living "in

translation" and speaking "two cultural languages, to translate and negotiate between them," as Stuart Hall has noted. ${ }^{5}$ However, there is a great deal of intersection between Palestinian nationalism, homeland kin relations (loyalty to clan, village, town, and region), and a reformed version of religiosity that operate in varying degrees 
among both immigrant and second-generation American Palestinians. These intersections can either restrict or increase women's agency in mate selection and marriage processes. Women cope with restrictions and find ways both to pursue their own choices and to satisfy parental/cultural expectations.

Among the second-generation, two age groups-over thirty-five years old and twenty-two to twenty-nine years old-differ in their upbringing, ideological orientations, and marital choices due to the historical contexts in which they were born and raised. Younger second-generation women who were born after the mid-1980s challenge national and cultural customs to assert their rights as women and control their own marriage process. The involvement of religious identity as a distinct mode of cultural self-concept has brought a different dimension to their negotiation of their roles and rights despite its own in-built limitations. This means that negotiating multiple identities allows women to express a broader sense of belonging that crosses national, ethnic, and class lines; this multi-cultural belonging in their temporal and spatial contexts changes women's situations and increases their agency. ${ }^{6} \mathrm{~A}$ constant rearrangement of hierarchal self-identifications reflects strategies to make social changes, including the institution of marriage and the criteria used to choose spouses. For example, for them, family-arranged in-group marriage processes are not essential to the maintenance of national customs. They do, however, incorporate cultural wedding ceremonies and rituals as a way to compensate for turning down parental and national values in marriage decisions. These ceremonies include the use of national symbols such as the Palestinian flag and kufiyah [headdress], national and cultural songs, and the black-and-white patterned headscarf that has become a symbol of Palestinian nationalism and resistance since the Palestinian Great Revolt under the British Mandate. The establishment of mosques and Islamic institutions since the 1980s as spaces for community activities helps enforce Islamic identity. However, the notion of diaspora, exile, and fear of losing their "Palestinianness" also influences their marriage choices, as many Palestinian women still prefer to marry a partner from the same cultural background if a compatible potential spouse is available. In any case, elements of traditional marriage patterns such as obtaining the parents' blessings, coordinating family interactions, and holding marriage ceremonies, continue as symbols of preserving Palestinian customs.

Changes in marriage standards, not only among Palestinians but also among other immigrant communities as well, "arise from the interplay between three social forces: the preferences of individuals for certain characteristics in a spouse, the influence of the social group of which they are members, and the constraint of the marriage market in which they are searching for a spouse. ${ }^{17}$ Additionally, educational and career pursuits, identification with a broader sense of belonging (i.e., religion), and diversity within the (Muslim) community are other social and cultural factors that influence marriage patterns among Palestinian Americans. Women who highlight their religious identity and adopt positions of gender equity as a means of gaining further agency and as a tool of negotiation within existing power relations also face problematic views of women's place in society. Thus, the younger generation of women, most of whom are college graduates, seek to rectify these forces and use the religious sources' emphasis on equity among all Muslims as a bargaining strategy for self-initiated relationships and intermarriages.

\section{HISTORICAL BACKGROUND}

Few Muslim migrants settled in Milwaukee before the Second World War. Most arrivals who came after the war were Muslim Arabs and reflected the national origins of their Arab Christian counterparts who took refuge in the United States in the late nineteenth and early twentieth centuries escaping from "persecution or marginalization" as well as overpopulation and economic adversity in the Ottoman Empire. ${ }^{8}$ Palestinians constituted the majority of Muslim immigrants living in Milwaukee, ${ }^{9}$ immigrating primarily as a result of the creation of the Israeli State in 1948 and the Israeli occupation of the West Bank, East Jerusalem, Gaza, and the Golan Heights in 1967. Palestinian immigrants were politically and culturally active. They formed organizations 
that integrated the community into American political and economic processes but also expressed pride in their national homeland and advocated for Arab culture and Pan-Arabism. ${ }^{10}$ The politics of inclusiveness allowed the Palestinian community to emphasize both their Arabism (and other narrow identities that reflects loyalties to region, town village, and tribe), and Americanism-especially within the community's local, regional, and national organizations such as the Arab Student Organizations (1960s and 1970s), the Arab American Association of Milwaukee (1960s), and hometown organizations and societies (e.g., al-Bireh Society, American Ramallah Federation). ${ }^{11}$

In the last three decades, Milwaukee became the destination for a significant number of Muslim immigrants from around the globe, particularly from South Asia and Arab countries where the political and economic climates led to an increased number of emigrants. These migrants strongly identified as Muslims and affected the way Arab Muslim communities perceived themselves in relation to their ethnicity and religion. This trend was part of global Islamic revival movements fueled by an increase in religious education and spread with advancements in communication. ${ }^{12}$ Indeed, locally and globally, a host of factors aided the Islamic movements, including the ongoing Arab-Israeli conflict and the War in 1967 with its territorial occupations. These events resulted in feelings of despair and betrayal among people across Arab countries, which caused them to question the legitimacy of their national governments. Other events, such as the civil war in Lebanon between 1976 and 1990, the Iranian Revolution of 1979, the Palestinian uprising in 1987, and the Gulf War in 1990, strengthened the Islamic mobilization in the Arab world and in their diasporas. ${ }^{13}$

The Islamic identity of the new wave of Arab and South Asian (mainly from India, Pakistan, and Kashmir) immigrants took precedence over their national and ethnic identities. ${ }^{14}$ The new immigrants played a major role in emphasizing the need for Arab American communities to establish Muslim institutions in order to preserve their Islamic faith. These efforts led to the establishment of the Islamic Society of Milwaukee (ISM) in 1980, which now functions as a major religious and cultural center for the community. ${ }^{15}$ The mosques and Islamic centers in the Greater Milwaukee Region include the ISM Main Center (and its K-12 school) and its two new Mosques: ISM Brookfield West and ISM University East. ${ }^{16}$ In addition, there are other Sunni Muslim mosques and centers, such as Masjid al-Quran, Masjid al-Dawa, Masjid al-Huda (with its newly established school in 2016), the Islamic Resource Center, the Turkish American Society, and most recently, Rohingya Masjid Mubarak. ${ }^{17}$ These organizations emerged as possible replacements for the national secularist movements that failed to solve the myriad political, social, and economic problems faced by people throughout the Arab world. Prioritizing religious identity validated the socialization patterns and self-initiated marriages outside the national group.

\section{FROM CROSS-BORDER BRIDES TO CROSS-BORDER GROOMS: ENDOGAMOUS}

\section{MARRIAGES}

Palestinian national identity along with homeland kin relations (loyalty to clan, village, town, and region) still operated strongly among the Palestinian diaspora as a result of witnessing the reality of the situation in the homeland through visits, learning about Palestinian experiences under Israeli occupation including lives in refugee camps in Arab countries through social media and technological communication, and immigrants communicating their recollections of colonial experiences of oppression to the subsequent generations. In addition, Arab and Palestinian organizations connected immigrants to their cultural roots and encouraged immigrants' children to interact within their own national and ethnic groups. Local and regional homeland organizations enforced kinship/regionalism (i.e., by marrying from the same village, town, and even clan or extended family), and they simultaneously advocated for pan-Arabism and a Palestinian national cause. ${ }^{18}$ They provided a means through which immigrants could donate their time and money to their national cause. The speakers at community conventions usually called for Arab unity, addressed the treatment of Palestinians under 
Israeli occupation, and discussed how to support the struggle for Palestinian statehood. Asma, who migrated from al-Bireh in 1966, commented on the function of the al-Bireh convention and her activities during this period, affirming "that [the convention] was for Palestine." She continued: "We used to raise money and so my daughters were involved; we were involved. I was involved [also] with the Rabitatilmara (Federation of Palestinian Women). We used to own a club and that was long time ago on North 27th street and St. Paul Street." ${ }^{19}$ The intersection between local and national loyalties is a component of the ongoing struggle of selfhood and nationhood since the nineteenth-century Nahda discourse of the Arab cultural renaissance. During the period between the 1950s and the 1980s, the Milwaukee Muslim community was composed mainly of Arab immigrants who succumbed to deeply ingrained nationalist ideologies, particularly with regard to Arab unity and the Palestinian national cause. ${ }^{20}$

Muslim women of this wave came as young brides joining their husbands who had previously lived in the United States for some years before they went "back home" to marry. ${ }^{21}$ Few women migrated along with their families as sisters or daughters, and fewer migrated alone as single women. ${ }^{22}$ Most of the Milwaukee Palestinian women who arrived in the 1950s through 1970s had either elementary, secondary, or high school diplomas. Their husbands, who usually had arrived to get education or work at stores and factories, obtained higher education or started their own businesses, including convenience stores and gas stations, in a couple of years. ${ }^{23}$ This trend paralleled other American families of the 1950s, where husbands typically had more education than their wives. ${ }^{24}$ Most of the Palestinian women who migrated between the 1950s and 1970s came from the Ramallah region and from cities, town, and villages such as Al-Bireh, Beiteen, DayrDibwan, Atara, and Jeljlyah. ${ }^{25}$ These women generally married between the ages of sixteen and twenty. Women from smaller villages and towns such as Jeljliyah usually got married by the age of sixteen or seventeen. Each woman has a unique story about her marriage process, but arranged marriages and early marriage age are common in their stories. Their marriages were also strictly endogamous; marrying outside the national or religious group was improbable, and marrying from the same village, town, or kinship was prioritized. ${ }^{26}$ For example, six of the nine interviewees in this group were from Al-Bireh and married to men from the same town and/or Hamula (clan). Three of these were married to a relative of their mother or father. These marriages were arranged by their families based on considerations such as maintaining kin relations, keeping property within the family/kin circle, or forming relations with a so-called good family. Parental pressure from both families had a very strong influence on the decision of both potential spouses to consent to the marriage. Most of the immigrant interviewees indicated that arranged marriages meant that their families were involved in all stages of marriage preparationespecially the initial stage of selecting and accepting the potential spouse. Sometimes a well-known woman or man acted as town matchmaker. Known as simsararayas, brides' intermediaries, these would be consulted to find an eligible young woman. Prior to a man's visit to Palestine, his family already would know about the purpose of this visit and engage in the search for a suitable bride. There were certain criteria for the match of a woman to the man; the primary criteria were the prestige and reputation of the family and its compliance with aspects of their own social class. The mother would conduct this search in the same area, clan, or village; cousins and relatives were favored above all. If she was unable to find one within this circle, she would go outside it. When a suitable girl was located, a background check would take place on the potential bride's behavior, her looks, educational level, and family reputation, and if positive, the groom's family would make a visit to ask for the girl's hand in marriage. The bride's family also completed their own background check, and then the potential spouses met under family or community surveillance to make the marriage decision in a short time.

Most of the interviewees revealed that they agreed to marry based on a combination of their parents' judgment and their own consent. A potential groom who resided in the United States was considered an advantage; many young women viewed this as a chance for a better life for themselves and greater educational and economic opportunities for their future children. Putting aside their lower agency in migrating, cross-border marriage migration enhanced the position of women in most cases. ${ }^{27}$ For them, arranged marriages were the usual and 
ideal way of getting married, and cross-border marriages got them beyond certain spatial and social constraints. Aliya immigrated to the United States to join her husband, who was distantly related to her own family, which was why her father wanted her to marry him. The rest followed the same pattern; the mother in law "knowing there is a girl, came back to Jerusalem; she wanted her son to marry an Arab woman." Aliya said that her marriage was "planned" and continued: "[L] ike a planned wedding: it was not like me meeting him. I was young, and I was just so happy; I wanted to come to America. I did not think." As proud as she was about her home, heritage, and family, she explained that the reason why she was content to marry was "because he was American citizen." As she anticipated, Aliya got cosmetology education and opened her own salon in the United States; however, she was disappointed with her marriage and pursued a divorce. The pressure she faced from her uncle in Palestine to remain in an unhappy marriage is indicative of the strong familial and cultural impositions on women even from thousands of miles away.

The fact that Palestinian women's migration to the United States was stimulated by individual autonomy but achieved as part of a family union is an indicator of the gendered aspect of both migration and marriage. As Aliya's case demonstrates, cross-border marriages aimed at co-ethnic marital unions, but they also meant more agency, mobility, and liberty for women, especially under the Israeli occupation. While family union was the main reason, women, with no less enthusiasm than men, sought opportunities in opting for (arranged) marriage migration. As Nicole Constable has noted, marriage migration "involves a similar desire to attain a more favorable position in the spatial hierarchy and to benefit from the advantages of a better location." ${ }^{28}$ Marriage migration is a global movement that produces similar outcomes in communities in which it happens. In her article on the gendered aspect of marriage migration, Minjeong Kim states that " $[\mathrm{m}]$ arriage migration led to social, demographic, and cultural transformations of current and future generations ... and raised new issues in relation to race, ethnicity, gender, class, and nationality." ${ }^{29}$ In the case of the Palestinians in Milwaukee, marriage migration constituted a Palestinian Muslim community consolidating within their own local community and yet well integrated to mainstream society through formation of families, educational integration of immigrants and their children, etc. The influences of marriage migration on the community are strongly felt in future generations as well, since the immigrant community, no matter how much oriented towards challenging physical and invisible boundaries, had a greater tendency to protect its tradition and culture. Therefore, crossborder spouses became the ideal for marriage and were imposed on their children as well; the daughters of the immigrant generation found their spouses in the homeland, and overseas grooms immigrated to the United States to join their wives. Until younger second-generation Palestinian Americans viewed such marriages as incompatible, many elder second-generation women married from overseas or from their local circle in the United States.

Typically in an arranged Palestinian marriage in the United States and West Bank, Palestine, as most interviewees explained, several steps would be taken leading to the wedding. The first was the tulba, a ceremony in which the groom and his family made a formal visit to the bride's house to ask for her hand in marriage. Tulba allowed the couple to learn more about each other, usually with a family member present. Once the couple and their families agreed upon the marriage, they would move forward with the legal marriage contract, katbkitab. This would take place before the wedding ceremony-from a few months after the tulba to a few days before the wedding. A couple of nights before the wedding ceremony, a henna celebration was held for the bride and the groom along with friends and family in which they had the opportunity to dress in traditional clothing and receive henna tattoos. ${ }^{30}$ Finally, the wedding ceremony was held, usually with a dinner, music, and dancing. These weddings and ceremonies continued customary mate selection processes, providing parents a chance to seek brides or grooms for their children.

Abiha is an immigrant woman who came to Milwaukee with her father as a teen in 1968. She finished high school in Milwaukee and then got married to a man from the same town in Palestine, Al-Bireh. He saw her at an 
engagement party and then called her father to ask for her hand in marriage. At that time, her mother was still living in Palestine, and when her father called her mother to let her know, Abiha's mother consented because the groom came from a good family. Abiha described that "they (parents) always look for the root of the family - that is very important. It [Al-Bireh] is a small city, so everybody knew who he is." Abiha has three sons and two daughters, and all of her children obtained college degrees. Three of her five children are married to spouses from Al-Bireh through the traditional arranged marriage process. Her youngest daughter was twentyseven years old and was engaged to a man living in Palestine at the time of the interview, which is one example of the practice of cross-border marriages among the second generation.

During this period, 1950s through 1980s, the marriages of the second generation of this group also tended to be arranged, but women now had a greater role in choosing their spouse than did their parents' generation. In addition, a longer and less monitored period of chaperoned dating usually took place. The small size and the composition of the community were limiting factors for the brides, who typically sought grooms who were Palestinian with higher education. Families in the United States from the same towns and villages stayed in contact with one another through local and national events and conventions. Apart from their social, cultural, and political functions to facilitate relationships among families and with their homeland, these events also encouraged the second generation to marry from within their own group. ${ }^{31}$

A significant number of the children of immigrants who were born before the mid-1980s married Palestinians either born in the United States or Palestine. Sanna, born in the United States, confirmed that "it is nice to be from the same village and same cultural background." Feda, the oldest daughter of Palestinian parents who migrated from Al-Bireh in the 1960s, married when she was eighteen years old to a second-generation engineer after receiving her high school diploma. Her two younger sisters, however, finished college and only then married American-born Palestinians. These grooms' parents were originally from the same town (Al-Bireh) as the girls' parents. The mother, who immigrated as the bride through cross-border arranged marriage, organized trips to their town and village in Palestine to look for potential suitors for her daughters. Thus, parents continued to seek marriage partners for their children in the local circle and arranged their marriages by bringing in cross-border grooms. Dina stated that she was supposed to marry not only a Palestinian but also someone from her hometown, Al-Bireh. She explained how towns of origin used to be considered as sources of difference: "Living in Louisiana, I was surrounded by people from all different towns from Palestine. It is funny, because you are all from the same place: it is Palestine. It is like you are from Wisconsin, but it is like Greenfield can be different. And the different towns; it is all very different." Yet, Dina pointed out that although back in the homeland, being from different towns would lead to considerable divergences, in the United States these differences could be ignored and people could unite around a more encompassing frame: their national identity. Therefore, the influence of local politics steadily decreased while new meanings and more importance were attributed to national, ethnic, and religious identity.

To fulfill their expectations, parents took or sent their children to the homeland. Dana, Lena, and Randa, born and raised in Milwaukee, went to visit Palestine with their parents and got married there at the ages of twenty, twenty-one, and seventeen, respectively. They then applied for spouse immigration visas and brought their husbands to live in the United States. Randa, however, has three younger sisters who all finished college. Each of her younger sisters met her husband in college in Milwaukee in the 2000s. Two of them married Palestinians, but one married a Moroccan. Randa and her sisters exemplify a notable division within American-born Palestinians: the divide between older and younger siblings. Older siblings tended to marry in the same national group and in significant numbers to overseas spouses-usually from the same area in Palestine as their parents. Their educational levels vary; very few have less than a high school education, and some had a few years of college. Among the group with less than a high school education, some finished their diplomas after they got married-as did Randa herself. The group of younger siblings, who reached the marriageable age in the 2000s, 
tended to have more choices due to multiple factors including their higher educational level, career attainment, and the growth of the Muslim community in the 1990s and 2000s. As the Muslim community became larger and more diverse, parents tended to loosen their expectations of marrying their daughters to Palestinians.

\section{SELF-INITIATED INTERMARRIAGES WITH CULTURAL PROCESSES AND CELEBRATIONS}

Most Palestinian women who migrated in the 1980s and 1990s came with at least high school or college degrees. ${ }^{32}$ between eighteen and twenty-four years old. Among the fifteen interviewees who migrated during this period, nine came from the Ramallah region with four-year college degrees and two with high school diplomas; two migrated from Kuwait with some college education, and two from Jordan with high school diplomas. Half of these women went back to school after migration either for undergraduate or graduate degrees. All of them married either before migration or came as fiancées and married in the United States. Among these, five women have the same level of education as their husbands, three have less education, and two have higher education than their husbands. Their marriage processes varied; those with college degrees met their husbands in college, and their marriages were not arranged. These women then went through the remaining arranged marriage process of background check, tulba, and Katb Kitab.

Similarly, the second generation born and raised in the United States during this period shows a deviation in their socio-cultural orientations, education level, and strong religious affiliations from their parents and elder second generation. Their level of education, interaction with Muslims from other racial and national backgrounds, and the unavailability of compatible potential spouses in their Palestinian community affected their partner selection and helped transform the marriage patterns of Palestinian immigrants and their children. First, all of them possessed at least college degrees and were employed. Nada commented on her generation's objectives: "Nowadays, I feel that girls are trying more to get educated before marriage. And I feel that they are delaying the age at which they get married." Palestinian American women now place more emphasis on their education and career goals, which are among the factors that have increased their negotiating power in the marriage process. Growing up as American Muslims in a multicultural and multi-religious society, attending community Islamic schools, and acquiring higher educational levels consolidated this young generation's diasporic identities. These identities, a product of their historical and social contexts, provided them with a dynamic understanding of Islam as a modern religion open into different interpretations, especially regarding the issues of marriage, divorce, and gender equality. When negotiating their choice and criteria of marriage partner, they used their identification as Muslim and American, not as Palestinian, to get their parents' consent. Moreover, few among them preferred to marry Palestinians who were born and raised in Palestine even if they were educated, as they see these men as culturally incompatible. This Islamic identity "legitimates increased individual control of marriage decisions," ${ }^{33}$ on to utilize this identity as a negotiating tool for their marriages. As Denise al-Johar confirmed, the role of education and religiosity promoted second generation Muslim intermarriage in the United States. ${ }^{34}$

A rough estimate suggests that there are between fifteen and twenty thousand Muslims in the Greater Milwaukee area. ${ }^{35}$ Newcomers from South Asia, Morocco, and Arab countries changed the demographic composition of Muslim communities in Milwaukee beginning in the 1980s. ${ }^{36}$ The size and ethnic composition of the Muslim community inform the degree to which women socialize and interact with Muslims and nonMuslims. The increased diversity of the religious community allowed for interactions among Muslims from different ethnic and national backgrounds, and Islamic institutions functioned as spaces for community, religious, and cultural activities. This interaction tended to fuse community members around one common shared Islamic identity. For this generation of Palestinian Americans, religion was the determining factor and assumed priority over the parents' culture. Women now perceive themselves in relation to cross-cultural, dual 
membership in mainstream and minority cultures. Farah, who went to Salam school for three years and then a Catholic school for girls and was actively engaged in Islamic organizations, identified herself as follows:

I identify first as Muslim, and then as American. I put me being Palestinian third only because of the fact that I was not born or raised there. I was born here so my culture is more American than it is Palestinian. But when people look at me, I actually say I am Palestinian because I know what they mean when they ask me "where are you from?" So I immediately say "my parents were both born and raised in Palestine." And I identify first with Islam because it is a lifestyle and I try to implement it in my everyday life-the hijab really helps with that; praying really helps with that. But I try to get the best out of the American culture and the best out of the Arab culture.

The way Farah self-identified points out the hierarchical mode of identification in which the affiliations are apt to change depending on the benefits brought or taken away, with national identity possessing the lowest level of importance and religious the highest. Strong affiliations with Islamic identity are closely related to the Islamic institutions as the embodiments of the Islamic revival movements. These movements signified a resurgence which challenged firm structures of social foundations of any other type. Individual and collective identities, gender roles, social organizations and institutions, marriage trends, and political activities were redefined and reconfigured by those who became subjects or objects of this revival. It allowed women to socialize in a larger community, negotiate their rights as women, and acquire more authority and agency in arranging their marriages.

Women increasingly established a new trend by practicing intermarriage-nationally, ethnically, and raciallythus decreasing their parents' involvement in the selection of marriage partners. They also postponed marriage, which increasingly changed their community's standard of marriageable age and informed the transformations in women's agency in the American Palestinian community. Among this second-generation group, three were married to Caucasian Americans who converted to Islam before marriage; three married Pakistani Americans; two married Moroccan Americans; two married Syrian Americans; one married a Palestinian living in Palestine (who migrated to Milwaukee to join his wife), and two remained in college, with one not considering marriage at that time. The parents of all of these interviewees were living in West Bank, Palestine before they migrated to the United States.

Muslim marriages across social, cultural, and ethnic boundaries receive less resistance from families than interreligious marriages. Even these, however, are usually gendered conversions in which the non-Muslim male usually converts to Islam. ${ }^{37}$ This is contrary to interreligious marriages in other societies, in which usually the women convert to Islam. ${ }^{38}$ That is because Muslim women's marrying non-Muslim men is interpreted as forbidden in Islam. According to "classical Shari'a regulations: a Muslim man may marry a Christian or Jewish woman but no other unbeliever; a Muslim woman may not marry a non-Muslim under any circumstances." 39 American Muslim women who married converts disclosed that their spouses' adoption of their religious beliefs was the only solution to get their parents' approval. This has grown to be a more common occurrence in other diasporic Muslim communities. Sindre Bandstad's study of the Muslim community in Cape Town, South Africa, unfolded that interreligious marriages do occur and are met with varying reactions. In these interreligious marriages, where one partner was Muslim and the other was non-Muslim, often the non-Muslim partner converted to Islam (67.9 percent). ${ }^{40}$

Even if intermarriages are not as harshly opposed as interfaith marriages, more often than not they indicated the tension between maintaining cultural consistency and the increasing demand for matching religious values. ${ }^{41}$ Zena was a thirty-three-year-old second-generation Palestinian American woman who indicated that the marriage process has changed since her older sister, who is ten years older than her, got married. She said: 
My sister is in her forties. Her generation got married very young because their parents did not know how to raise their kids in the United States. They got their kids married very young, like right out of high school or before high school, and then they got married usually to people from overseas. The Arabs and Muslims around my age are completely different; lots of them are still not married, the few that are married do work and they do have kids.... So it has changed because I think it depends on how long the parents have been in the United States and have adapted to American culture.

As she explained, Zena's sister married before high school to a relative from her parents' village in Palestine. However, Zena and her other sisters married men of their choice. Zena married a Moroccan whom she met in college. Zena predicated the change in parents' perception of ideal marriage age on adapting to "American culture," and for her own marriage, it was her spouse's Muslim identity that motivated her to proceed with her relationship, wielding it as a negotiating token that allowed her to gain her parents' blessing. Most of the interviewees who married outside their group indicated that great strength and a good deal of convincing were required in order to obtain parents' permission. Mothers usually were the sole supporters of daughters' desire to marry outside the ethnic community. They often contributed to easing the process of negotiation, convincing the father of the suitability of the potential spouse and supporting and strengthening their daughters' determination to marry a Muslim spouse of their choice - regardless of his national origins. Ayda explained her mother's position in encouraging her to ignore the reactions:

I thought my mom would care that he was not Palestinian; she actually is the one who [encouraged me]. Because I was really self-conscious about it [his not being Palestinian], I was the very first in my family and my extended family, even further, distant, farthest family you can think of, who has not married a Palestinian. And especially following the steps of my sister, who married a guy who was from the exact same village, I knew that I would be dealing with a lot, and my mom really put into perspective that, it really was not a big deal, and that stuff [community gossip about her not marrying a Palestinian] would only last a couple months but a marriage lasts a lifetime. And that stuff is insignificant, so it was definitely my mom [who encouraged me].

The reasons for mothers' support of their daughters' intermarriage are connected to each family's situation. For example, Ayda's mother had a college degree, but education was not the only reason for her encouragement. Her interaction with Muslim and non-Muslim communities; the religious rhetoric that emphasizes the Muslim identity of the umma [Muslim community]; and, more importantly, the influence of the second generation on changing their parents' perspective toward the criteria of the potential spouse led to education level and religion taking precedence over national origin. Also, after marrying her oldest daughter to a Palestinian from her original village in Palestine, the obligation of staying connected to homeland was partially fulfilled. Undoubtedly, there is also a domino effect on intermarriage; prior to her marriage decision, Ayda's friends from two Palestinian families intermarried to non-Palestinian Muslims, one of them to an American convert and three to American South Asians. Similarly, her intermarriage encouraged her female cousins and others from her generation to marry outside their national and ethnic group. A year later, Ayda's cousin married an American Pakistani.

The fear of not finding the right match played an important role in women's negotiation with their parents as well as marrying outside a national group. Ayda met her husband at the local religious center in 2009 and married him in 2015. It took her a few years to get her family to accept him because he was not Palestinian. After she got engaged, members of the Palestinian community questioned her decision to marry a Syrian. For Ayda herself, a potential groom's national background should not have been the primary form of identification. This view presented difficulties among her Palestinian community, as "people would not identify him as an engineer, as a Muslim, or as an Arab. But the first thing that they would mention was his [Syrian] culture." She confidently explained to them that her decision "was not like haram [forbidden in Islam] or ayb [shameful]." She 
confirmed that her friends, who were mainly second-generation Muslim women, "cared more about how he looked and what he did for a living" than his national origins. However, Ayda's identity as a Palestinian American is still important to her. She explained her mixed feelings about marrying outside of her national group:

He was the guy that fit all of my dad's expectations except for one, which was that he was not Palestinian. So, when he came to ask for me, I instantly knew that it was going to be a problem, but I also knew that he fit all the other criteria so it was not as bad as it could have been. Me and my dad both have the same expectations, and to be honest, I would want-just because of what is going on overseas, I would want my children to be 100 percent Palestinian. I mean it is the dream. It is what I would want - I want -I want that for my family and just for the future of Palestinian people. But I mean if I sat around all day and waited for somebody who was compatible with me and who met all the expectations that I had, all the expectations my dad had, and who was Palestinian, I would be-I would never get married.

Ayda's feelings of obligation toward her national group reflect the dynamism between diaspora and homeland among Palestinians in diaspora. It also shows that marrying a Palestinian is a first choice, and yet a "dream;" marrying from the same national group is not realistic as much as it is desired. Yet, the fact that it cannot be fulfilled does not really bother most of the women because for many second-generation women, their diasporic identity should be seen as "an idiom, a stance, and claim" for mobilization and strengthening of group loyalties and sustainment of the imagined homeland traditions and customs. ${ }^{42}$ The romanticizing of homeland culture, their parents' nostalgic remembrance of their lives in Palestine, frequent visits to their parents' homeland and accessibility of transnational communications, and the ongoing Palestinian Israeli conflict are among the mobilizing forces for the second generation to "adopt a diasporic stance" 43 that includes the preserving of their parents' societal standards and wishes. The choice to marry within the group should be seen, as with other forms of cultural and social conservatism, to preserve group unity and reinvent Palestine, "figuratively and literally;" 44 as Ayda said, it is seen as a way to contribute to "the future of the Palestinian people."

Therefore, adopting and prioritizing religious identification among American Palestinians did not result in the dismissal of Palestinian national politics and identity. Indeed, internationalizing the Palestinian cause in humanitarian terms and the rise of international advocacy movements, such as the International Solidarity Movement, increased public awareness about the situation and the unjust treatment of Palestinians. During this period, homeland national organizations adopted and incorporated the era's religious discourse, and a number of religious organizations were founded. For example, the American Muslims for Palestine, founded in 2005, was formed to educate the public about the Palestinian plight and the Israeli occupation's atrocities against Palestinians and to enforce Muslims' duty to support the Palestinian cause. ${ }^{45}$ Hence, the Palestinian cause has no longer been perceived as a Palestinian or Arab issue; more recently it has been treated as a Muslim, and in general a global human rights and social justice movement. This goes beyond helping to consolidate the young generation's Palestinian identity. Accordingly, national or ethnic identity and feelings are not prioritized in social life, marriage decisions, or daily practices. Rather, they are expressed and exhibited with pride through symbolic and ritualistic practices such as traditional ceremonies and cultural clothing. In her study on the Palestinian community in New York, New Jersey, and Pennsylvania, Randa Serhan explains that American Palestinian community events such as weddings are a form of resistance. "[T] he Palestinian flag, scarves, kaffieyb-covered rods, and flag-colored masabih have become ubiquitous at weddings. As these practices emerged after 1987, weddings between Palestinians became Palestinian weddings" 46 as the Palestinian American community "sees itself as safeguarding its heritage, remaining true to its traditions, and preserving Palestine and its history." 47 Weddings represented more than the celebration of the marriage of two people; instead, they symbolized the cultural identity and cultural clash more than ever. Interestingly, Farah's parents' first consideration when she communicated her desire to marry a Pakistani was "how to make the wedding, the henna." She continued: "My 
mom was freaking out that I was not going to be wearing the thobe [traditional Palestinian dress]. And every time she would start freaking out, I would say 'mom, just wait until you see it."' Farah thought, "their doubts stemmed more from how to go about things with the community than anything else. And there was a culture clash too, specifically the differences in how the two families have their weddings." Ayda, who wished to marry a Palestinian but ended up marrying a Syrian, faced a great deal of community reaction. She organized her wedding as it is practiced in her village. She followed each process of tulba, which she described as "an old-time dating period," although she had already met her spouse at a religious program; khutba, "which is an engagement party"; henna; and wedding.

In brief, women challenge, act, and react to their realities using their "fluid and multiple identities." Their adoption of certain cultural traditions over others and their prioritization of Muslim identity in an era of Islamic discourse are ways of coping with living in diasporic communities informed by gendered cultural practices. The marriage process is one of the indicators of women's power or its lack in negotiating their social rights and roles. While definitions of marriage among first and second-generation American Palestinian women vary depending on the historical context, level of education, career goals, and family background, women increasingly become aware of and adopt the discourses and strategies that increase their agency in marriage decisions. As a result, religious identity has become the most important factor in determining marriage partners and convincing parents. Nevertheless, the position of Palestinians as a displaced population living in fear of losing their connections to the imagined and real homeland and traditions complicates their choices and exerts an undeniable influence on their in-group marriages.

\section{NOTES}

1. A portion of the oral interviews used in this study were conducted as part of a large oral history project that has been taking place since 2010. The project is led by the Arab and Muslim Women's Research and Resource Institute (AMWRRI), a nonprofit organization that focuses on collecting the narratives of women from the Arab and Muslim communities in the greater Milwaukee region.

2. Enaya Othman, "Arab-American in Milwaukee: History and Assimilation" (master's thesis, University of Wisconsin Milwaukee, 1998).

3. As a point of clarification, I am using the term "first generation" to apply to immigrants who were born outside the United States, and "second generation" for their American-born children.

4. AMWRRI was established in $\mathbf{2 0 1 0}$ with a mission to collect the histories and experiences of Arabs and Muslims in the United States.

5. Stuart Hall, "The Question of Cultural Identity," in Modernity and Its Futures, ed. Stuart Hall, David Held, and Tom McGrew (Cambridge: Polity, 1992), 310.

6. Roger Brubaker, "The 'Diaspora' Diaspora," Ethnic and Racial Studies 28, no. 1 (2005): 12; Judith Butler, Excitable Speech: A Politics of the Performative (New York: Routledge, 1997); Chandra Talpade Mohanty, "Under Western Eyes," in Third World Women and the Politics of Feminism, ed. Chandra Talpade Mohanty, Ann Russo, and Lourdes Torres (Bloomington: Indiana University Press, 1991), 51-80.

7. Matthijs Kalmijn, "Intermarriage and Homogamy: Causes, Patterns, and Trends," Annual Review of Sociology 24, no. 1 (1998): 398.

8. Alean Al-Krenawi and Stephen O. Jackson, "Arab American Marriage: Culture, Tradition, Religion, and the Social Worker," Journal of Human Behavior in the Social Environment 24, no. 2 (2014): 117-24.

9. Othman, "Arab-American in Milwaukee."

10. For more information about these organizations see Enaya Othman, "'Strategies of Recognition' and Palestinian Immigrant Women's Cultural Dress: Forging Communities and Negotiating Power Relations," Journal of New Middle East Studies 5 (2015): 1-15; Adnan Ahmad, interview, May 4, 1998. Ahmad was a community organizer and a leader in the 1970s and 1980s in Milwaukee. 
11. Ahmad, 1998. Ahmad listed examples of these organizations including American Federation of Ramallah (1952), Al-Bireh Society (1980s), the Arab Student Organization (1960s), the Arab American Association of Milwaukee (1960s), the University of Wisconsin Milwaukee Student Chapter (1970s), the University of Wisconsin Milwaukee Muslim Student Association (1970s), the Arab-American University Graduates (AAUG) (1967), the National Association of Arab Americans (NAAA) (1972), the American-Arab Anti-Discrimination Committee (ADC) (1980), and the Arab American Institute (1985). It is worth mentioning that these organizations exemplified the type of unity that Arabs from Muslim and Christian religious backgrounds intended to demonstrate.

12. Oliver Roy, Globalized Islam: The Search for a New Ummah (New York: Columbia University Press, 2004); Also, for more information on Muslim revival, see John L. Esposito, Women in Muslim Family Law (Syracuse, NY: Syracuse University Press, 2001).

13. See Leila Ahmad, The Veil's Resurgence, from the Middle East to America (New Haven, CT: Yale University Press, 2011).

14. Othman, "Arab American in Milwaukee."

15. Dr. Waheed al-Deen Ahmed, a Pakistani immigrant who settled in Milwaukee in 1977, was an instrumental figure in establishing the Islamic Society of Milwaukee, ISM. He talked about the Muslim student organizations and Doctors Association, which was called "The Islamic Foundation of Greater Milwaukee"; he got together and purchased this center on South 13th Street and Layton.

16. For more information on ISM history and activities, see their official website: http:// www.ismonline.org/

17. There are also other non-Sunni Muslim sects in Milwaukee, such as Dar-ul-Hikmah, a Shia Ithna Asheri Muslim religious organization, and Masjid Bait-ul Qadir, that belong to the Ahmadiyya group. For more information, see Annysa Johnson, "Ahmadiyya Muslims Worship Freely Here, but Persecuted Elsewhere," The Journal Sentinel (Milwaukee, WI), June 22, 2013, http://www.jsonline.com/news/ahmadiyya-muslims-worshipfreely-here-but-persecuted-elsewhere-b9957553z1-216452141.html; on Dar-ul-Hikmah see http://www. darul-hikmah.org.

18. Ahmad, 1998; in an interview with the author and multiple informal discussions, Ahmad explained the community cultural and national activities and the functions of homeland organizations such as Al-Bireh American Society and the national politics of the period.

19. Othman, "Strategies of Recognition," 7.

20. Othman, "Arab-American in Milwaukee," 51.

21. Enaya Othman, "The Immigrants to Milwaukee from the Arab World," Arab and Muslim Women's Research and Resource Institute Website, AMWRRI, http://amwrri.org/articles.htm (accessed July 3, 2013).

22. Othman, "Arab-American in Milwaukee."

23. Othman, "Arab-American in Milwaukee."

24. Christine R. Schwartz and Robert D. Mare, "Trends in Educational Assortative Marriage from 1940 to 2003," Demography 42 (2005): 621.

25. Ramallah and Al-Bireh were the two major large towns that developed into the two largest cities since the 1990s.

26. These were consanguineous marriages.

27. Danièle Bélanger and Tran Giang Linh, "The Impact of Transnational Migration on Gender and Marriage in Sending Communities of Vietnam," Current Sociology 59, no. 1 (2011): 62; Nicole Constable, "A Tale of Two Marriages: International Matchmaking and Gendered Mobility," in Cross-border Marriages: Gender and Mobility in Transnational Asia, ed. Nicole Constable (Philadelphia: University of Pennsylvania Press, 2005), 177. 28. Constable, 177.

29. Minjeong Kim, “Gender and International Marriage Migration,” Sociology Compass 4, no. 9 (2010): 718. 
30. Enaya Othman, "An Arab Henna Night United Milwaukee Communities," Al-'Athr (The Trace) editor Column 2, no. 2 (May 2013): 1-2, https://amwrrisite.files.wordpress

31. .com/2017/03/jmnfky-amwrrinewslettermay.pdf.

32. Othman, "Strategies of Recognition," 5.

33. Othman, "Arab-American in Milwaukee."

34. Denise Al-Johar, "Muslim Marriages in America: Reflecting New Identities," The Muslim World 95, no. 4 (2005): 557.

35. Al-Johar, "Muslim Marriages in America," 557-74.

36. Othman, Atta. "Muslims in Milwaukee: A Brief History." Islamic Society of Milwaukee: 25 Years of Service 1982-2007 (printed booklet for the 25th anniversary, 2007). Usually Muslim leaders estimate the population at fifteen thousand, based on the size of their congregations. However, there are a number of Muslims who are not Mosque goers and these can be estimated as at least five thousand individuals.

37. Immigrants from Kuwait are originally Palestinians who fled to the Gulf States after the creation of the Israeli State and then to the United States during the Gulf War in 1990-1991.

38. Egon Mayer, "Processes and Outcome in Marriage between Jews and Non-Jews," American Behavioral Scientist 23 (1980): 487-518. Mayer's study emphasizes that the conversion of one of the spouses was the common practice in interreligious marriages.

39. Sithi Hawwa, "From Cross to Crescent: Religious Conversion of Filipina Domestic Helpers in Hong Kong," Islam and Christian-Muslim Relations 11, no. 3 (2000):347-67.

40. Alex B. Leeman, "Interfaith Marriage in Islam: An Examination of the Legal Theory Behind the Traditional and Reformist Positions," Indiana Law Journal 84, no. 2 (2009): 755.

41. Sindre Bangstad, "When Muslims Marry Non-Muslims: Marriage as Incorporation in a Cape Muslim Community," Islam and Christian-Muslim Relations 15 (2004): 349-64. Interreligious marriages are met with various reactions, as Bandstad's study shows, even though they do occur in Muslim groups. In these interreligious marriages, where only one partner identifies as Muslim, it was often the non-Muslim partner that converted to Islam (67.9 percent), followed by the spouses each maintaining their own respective religions (11.7 percent) and only 1.5 percent of Muslim partners converting to their partner's religion. Bangstad shows both a malevolent and a benevolent reaction to intermarriage. While Andrzej Kulczycki and Peter Lobo found that "rates of out-marriage are still high" among immigrant Arabs, this is truer among Arab Christians than Arab Muslims. Nevertheless, since the late 1990s, there is an increasing trend of out-marriage in Muslim American communities-especially among women in interreligious marriages, in which the male usually converts to Islam prior to the writing of the religious marriage contract. Intermarriage cases in the Palestinian community show that they are still mainly within the same faith group, and women face challenges from parents. See Andrzej Kulczycki and A. Peter Lobo, "Patterns, Determinants, and Implications of Intermarriage among Arab Americans," Journal of Marriage and the Family 64, no. 1 (2002): 202-10.

42. Zareena A. Grewal, "Marriage in Colour: Race, Religion and Spouse Selection in Four American Mosques," Ethnic and Racial Studies 32, no. 2 (2009): 339.

43. Brubaker, "The 'Diaspora' Diaspora," 12.

44. Ibid.

45. Randa Serhan, "Palestinian Weddings: Inventing Palestine in New Jersey," Journal of Palestine Studies 37, no. 4 (2008): 23-24.

46. For more information check the organization website at:

https://web.archive.org/web/20151124001712/http://www.ampalestine.org/index.php/amp-publications.

47. Serhan, 27.

48. Serhan, 32. 
